\title{
Teaching Religious Education in Schools and Adolescents' Social and Emotional Development. An Action Research on the Role of Religious Education and School Community in Adolescents' Lives
}

\author{
Marios Koukounaras Liagkis \\ National and Kapodistrian University of Athens, Athens, Greece
}

\begin{abstract}
The presentation of the findings of this article is based on an action research focused on the supportive role of the school in adolescents' lives, whereby Religious Education's contribution to the social and emotional development of adolescents (11-15) is combined with the evaluation of the potential offered by a constructivist approach to the learning process. The research commenced in 2012 and is now in its third year. The project is based on an intervention at a high school in an impoverished suburb of Athens and researches educational practices through interpretative-ethnographic methods. The researcher has attempted to answer the question of whether the design of the learning environments is effective not only in the learning process, but also on inter-communication and "connectedness" between the members of the learning community. The findings so far indicate a correlation between adolescents' emotional and social wellbeing and the school's approach to knowledge and learning methods, specifically in Religious Education classes. It is fair to say, however, that there exist ethnic, social and family components that are negatively related to a sense of "connectedness" within the school although at the same time Religious Education as a subject is, however, found to be positively related to learning community atmosphere.
\end{abstract}

Keywords: Religious Education, well being, action research, constructivism, learning community

\section{Introduction}

There is a widespread belief that educational institutions play an important role in structuring people's identities and academic performance. This paper, however, argues in favour of the supportive dimensions of the school for which the research is, so far, less certain, and more specifically the contributions that the subject of Religious Education (hereafter RE) makes to early adolescents' social and emotional wellbeing and connectedness within the school space. The action research conducted since 2012 by two researchers in Greece, and its findings are the basis for this paper, which takes into consideration the role of the school in early adolescents' lives.

\footnotetext{
Marios Koukounaras Liagkis, B.A., M.A., Ph.D., Lecturer in Religious Education, Department of Theology, National and Kapodistrian University of Athens.

Correspondence concerning this article should be addressed to Dervenakion 1, 14121, Neo Iraklio, Greece.
} 


\section{Early Adolescents and Wellbeing in School}

Early adolescents, aged between 11-15 (Hamburg, 1974; Thornburg, 1983), are engaged in a constant struggle to confront self-identity problems while attempting at the same time to cope with increasing levels of uncertainty in a globalizing situation that has been stigmatized by a deep financial, social and moral crisis (Schwartz, 2008). The "dialogical" self emerges from the social, historical and societal processes that transcend any individual-society dichotomy or separation (Hermans \& Hermans-Konopka, 2010, p. 1). As self and society are interconnected, it is a truism to say that where education dominate adolescents' lives, at least in the western world, school might play a central role in allowing adolescents to recognize their own self-identity. School can have supportive dimensions ranging from paying attention to issues such as adolescents' relationships with each other and with their teachers, to their satisfaction with their educational experiences and to their membership of the school as a learning community in which they actively participate (Goodenow, 1993; Payne, Conroy, \& Racine, 1998; Reddy, Rhodes, \& Mulhall, 2003; Shochet, Dadds, Ham, \& Montague, 2006; Bond et al., 2007; Archambault, Janosz, Morizot, \& Pagani, 2009; Wubbels, den Brok, van Tartwijk, \& Levy, 2012). The aim of the school is not only to promote academic achievement, but also to enhance the students' and teachers' sense of "connectedness", both with the institution and the learning experience.

The concept of school connectedness is of relatively recent provenance although its components are of much longer standing. Student-teacher and student-student interactions can promote student motivation and affect subsequent performance, a notion derived from interpersonal theory and especially from theoretical perspectives on person-environment fit and personal goal setting (Eccles \& Midgley, 1989; Bronfenbrenner, 1989). Recent research argues that school-related competence is achieved to the extent that students are able to accomplish both personal and socially valuable goals, in a manner that supports continued psychological and emotional wellbeing (Wentzel, 2012). The HBSC (Health Behaviour in School-aged Children) data (2012) highlighted the youngsters' relationship with schooling and how much they "like school" —in other words, their levels of satisfaction with their experience at a Greek school. A positive answer to that question shows a marked decline from the age of 11 to aged 15 and Greek students aged 13 (Greece, Slovenia, Italy, Estonia, Croatia) and aged 15 (Luxemburg, Greece, Italy, Estonia, Croatia) appear in the bottom five amongst students of 39 countries who liked school a lot. A recent research in Great Britain reveals what is most important for our research since it offered the basic criteria for studying connectedness: (a) Young people as they get older develop a greater sense of detachment from their schools and teachers; (b) a minority of young people develop a sense of alienation; (c) components of positive feelings for schooling and greater feelings of "school connectedness" which emerge with considerable frequency are the relationships with teachers, relationships with peers and general satisfaction with the educational experience (Gray, Galton, McLaughlin, Symonds, \& Symonds, 2011, p. 103). Additionally, connectedness seems to be a matter of feeling that they belong in some way to the school community (Finn, 1993) and that they are cared for by people at school (Eccles, Early, Frasier, \& Belansky, 1997; McNeely, Nonnemaber, \& Blum, 2002). Not only is school a "learning community", but the sense of being a member gets stronger according to the extent to which the students participate in and exercise "voice" in relation to their schools' affairs and activities (Gray, Galton, McLaughlin, Symonds, \& Symonds, 2011). A recent review by Swedish researchers indicates that young people's academic performance at school and their levels of mental health and wellbeing are intimately related (Gustafsson et al., 2010). Young people's social and cognitive development and the degree of early adolescents' engagement with school which 
leads to a sense of achievement and high self-esteem, are both crucial and fundamental to their wellbeing (Finn, 1993; Marks, 2000). Conversely disengagement from school and poor relationships with teachers and peers are related not only to a higher risk of displaying anxiety or depressive symptoms amongst young adolescents but also to drug use, engagement in socially disruptive behavior and dropout from secondary school (Archambault, Janosz, Morizot, \& Pagani, 2009; Maens \& Lievens, 2003; Marcus \& Sanders-Reio, 2001).

International literacy stresses the need for giving greater attention to issues of wellbeing. There is, however, a finding, which both underpins and underlines our research namely that the most important factor affecting young people's wellbeing relates to the cultures of support their schools develop and sustain. The question is whether religion in education and especially RE as a curriculum subject is able to contribute to young people's social and emotional development.

\section{Religion in School and Religious Education as a Factor of Wellbeing}

The European public arena has been inundated with a wide range of debates related to the role of religion in education and moreover, to the impact of RE on societies and social cohesion. What is natural is that people question why RE is still on the curriculum when science displaces religion and, therefore, challenges the very appropriateness of the activity of RE (Bausor \& Poole, 2002).

$\mathrm{RE}$, however, remains a part of the schooling system in most countries. Different countries correlate to different stated policy intentions for RE in schools that are enacted through the different pedagogical practices of teachers in classrooms. At the same time, RE is influenced not only by the idea of secularity, but also by the extent of the secularisation of the state which determines the type of RE wherever it exists. Moreover, RE has equally been influenced by the historical context and experiences of each country and so is, in each situation, confessional or non-confessional, compulsory or optional. There are countries that are committed to a strict separation of religion and state (France) or strict separation of religion and education (ex-communists Balkan countries), where RE does not feature as a subject in the curriculum (Lähnemann, 2011). RE, as well as religion, survives in schools and in many respects is flourishing, because it is mainly a powerful anti-indoctrinatory subject promoting thinking in depth (Watson, 2012), a development of tolerance, a culture of "living together" and a recognition of different identities on the basis of human rights (Jackson, Miedema, Weisse, \& Willaime, 2007).

At the very least, a fruitful discussion is taking place in Europe regarding Religion and Education. There has been a dialogue for inter-religious and intercultural education since 2001, and different declarations, recommendations and projects illustrate the growing interest in RE (Koukounaras Liagkis, 2012). The Committee of Ministers agreed to a policy recommendation CM/Rec (2008) 12 (Council of Europe, 2008) that all member states should include the impartial study of religions within the curricula of their school systems. This recommendation gives a compelling cultural argument for the study of religions and incorporates ideas from the White Paper on Intercultural Dialogue which emphasizes the great importance and relevance of interreligious dialogue (Council of Europe, 2008). Of course in Europe, when one speaks of RE, has to bear in mind, moreover: (1) The Toledo Guiding Principles on Teaching about Religions and Beliefs in Public Schools (OSCE, 2007) and (2) the recommendation 1720/2005 (Council of Europe, 2005).

The REDCo (Religion in Education. A Contribution to Dialogue or a Factor of Conflict in Transforming Societies of European Countries) project which included nine projects from eight different European countries, from 2006 to 2009, emphasizes that religion must be addressed in schools, as it is an important factor in social 
life and for the successful coexistence of people from different cultural and religious backgrounds throughout Europe (Weisse, 2009). Moreover, the research put forward that personal contact helps to overcome separation and xenophobia. Within schools the issues of religious affiliation and experiences with religion in education have had quite an impact on how students look upon RE (Valk, 2009). The social dimension, however, of learning about religion in school is much more accepted and appreciated by students than the personal dimension (Bertram-Troost, 2009). However, it cannot be ignored that RE in classrooms provokes challenging questions about the ultimate meaning and purpose of life, beliefs about existence and God, the self and the nature of reality, the concept of right and wrong and what it means to be human. According to Unesco's first principle of intercultural education, education should respect the cultural identity of the learner whose religion is a factor in the formulation of that identity. Thus the use of curricula and teaching and learning materials should introduce the learners to an understanding and an appreciation of their cultural heritage and the teaching methods should be based on practical, participatory and contextualised learning techniques that are linked to the community's social, cultural and economic needs (Unesco, 2006, p. 35).

Students agree that RE plays a more significant role than most other subjects in preparing young people to live and work in a diverse society (Conroy, Wenell, \& Lundie, 2013) while sharing the belief that diversity is a value leading to tolerance and openness to dialogue regardless of their faith or no faith. Indeed, religious students feel that they are not less open to dialogue on religious issues than non religious students and that is a component of designing RE's curriculum (Beraud, 2009). Above all, religion is a factor of social development and behavior as it has a strong influence and mostly positive outcomes (Regnerus, 2003), on early adolescents' personality and their perspectives of life and reality (Saroglou, 2014).

But when we talk about religion in education, identity issues and socialisation in a pluralistic world there is a profound complexity (Arweck \& Jackson, 2014). Pedagogically, there is a chain with a sequence of links which fluctuates with the RE teacher's responsibility and enables learners to follow and react, but is fully demonstrated in the curriculum. The links are global and national context, national definitions of education and curriculum, definitions of rationale and scope for RE, definitions of progress in RE (e.g. attainment targets and level statements), RE pedagogies, teachers' apprehensions of all the above, the construction of a teaching and learning methodology and teachers' choice of classroom strategies/activities and techniques (Chater \& Erricker, 2013). R. Jackson believes that Rec (2008) 12 of the Council of Europe, which was mentioned above, offers solutions. The fundamental goal of the religious dimension of intercultural education is to develop an understanding of religions while in the case of religious believers, competence in "religious understanding" (see below) can often complement or contribute to competence of the above (Jackson, 2014). School is the "safe place" (Holley \& Steiner, 2005) for students to express their views and positions openly, even if these differ from those of their teacher or peers (Jackson, 2014). Furthermore, Grimmitt's pedagogical constuctivist approach (2000) offers a basis for further production in RE pedagogy and research such as ours (Erricker, 2010; Roebben, 2011).

\section{Teaching Religious Education in Greek Schools and Research on Its Relationship With Adolescent Wellbeing}

\section{Religious Education in Greece}

$\mathrm{RE}$ is an ordinary subject in the Greek school system. It is provided for all children: (a) In primary school for a period of four years for two hours per week (3rd, 4th, 5th and 6th grades); (b) for the three years of high 
school (Gymnasium) for two hours per week; and (c) for three years of General Education (Lyceum) for two hours per week for 1st and 2nd grades and 1 hour per week for the 3rd grade or for two years (1st and 2nd grades) of Vocational Education (Technical Lyceum) for one hour per week.

The majority of the population belong to the Orthodox Church, although the state does not keep numbers anymore concerning the religious landscape of religious believers or non believers. There are a number of Muslims including migrants and the Muslim minorities who live in Thrace (North Greece) and who are recognized as a minority according to the Lausanne Treaty (1923), together with minorities of other religions. For those students of the Muslim Minority in Thrace, the State enacted an Islamic RE with an Amendment (2013) of Law 3536/2007. Islamic RE started in 2013-14 and now is being taught for a second year in Greek schools in Thrace (Koukounaras Liagkis, 2013).

The framework for RE in schools is provided by the Law for Education (1566/1985) which stipulates that all students, on a mandatory basis, have to have been taught the "authentic" tradition of the Orthodox Church (article 1, paragraph 1). Besides article 13, paragraphs 1-2 of the constitution guarantee the basic right to freedom of religion and associate it with the development of religious consciousness. Moreover, the State has to provide RE to any religious community who wants to organize its RE on condition that five students apply for it. Of course, every student has the right to be exempted from RE lessons through an application, which must be signed by the two parents, pertaining to reasons related to religious consciousness and other doctrine or religion.

Several interpretations of the legislation above espouse several approaches to the pedagogical and theological area for the context of RE though the official organisation (Pedagogical Institute-now Institute of Educational Policy) which has had the responsibility for contributing to the curriculum states that RE tries to be faithful to the transmission of democratic values and critical openness. Thus RE has been considered since current reform of the curriculum of compulsory education in 2003 and until now, as an open-ended educational process that does fair justice to religious pluralism (Yangazoglou, 2007) whilst providing religious literacy and supporting students in developing their cultural identity by teaching mainly Christian Orthodoxy, other Christian traditions, world religions and worldviews (Curriculum 2003). A new curriculum for 7 years (starting in the 3rd year) in compulsory education (9 years) was introduced in 2011 and is only running through a pilot scheme in specific schools until now while the State has recently proceeded to introduce a totally new RE curriculum for the 3 last years of General Education (Lyceum). Both are pedagogically post-modern designed curricula and are basically based on the constructivist approach to RE, deriving their content more from "Religious Studies" (related to different religions, cultures and traditions) than "Theology" (related to particular religion and faith) as the curriculum of 2003 does.

\section{Religious Education in Our Action Research}

Our in-depth research attempts to illustrate the role of RE in Greek education, and its aims and contribution to early adolescent social and emotional development. Of course, the two aforementioned new curricula provide a more pedagogical framework than the previous one of 2003 and, therefore, they were the basis for the action-research.

Therefore, our consideration is how religion and education can be brought into a relationship which reflects why and how students benefit from the study of religion, and what methodologies, aims, and content would enable knowledge and learning outcomes in terms of the constructivist approach to knowledge (as a 
human construct which is a consequence of the way in which individuals and communities order their experience) (Grimmitt, 2000, $\sigma \sigma .18,208$; Dewey, 1958). Subsequently RE is totally based on knowledge procedures (Kalantzis \& Cope, 2012) and has a more person-centred approach, being in the service more of education than of religion and recognizing the highest priority of the method rather than the content. That means that constructivism, anthropology and theology provide what can be applied to RE and its representation of religions. On the one hand religious knowledge is deemed as a study of the "grammar" of the culture (Geertz, 1983) which enables individuals and communities to communicate with themselves, others and the transcendence and on the other hand RE can offer a platform for interactive, conceptual and interdisciplinary inquiry (Erricker, 2010) in order for students to engage in interpretation of the conceptual constructs that underpinned worldviews of themselves, others and different groups (Vygotsky, 1978). It is an exploration of the sense of personal and communal identity.

Religious literacy is prominent not only in the literature on RE, but in our research also. As there is no consensus view on that issue (Jackson, 2014, p. 30) clarification is needed that religious literacy is related, of course, to learning about religions, but also about developing students' religious understanding of themselves, the others and the world, as well as offering a religious lens through which they can conceptualise life by being constructivists in response to a new perspective that offers RE (Grimmitt, 2000, p. 47; Walshe \& Teece, 2013). There is no doubt that the first level of the attainment target includes "understanding religions" that enables students to develop an understanding of religions and the perspectives of religious people. The techniques that are required involve not only the acquisition of knowledge, but also the development of skills and the cultivation of various appropriate attitudes (Jackson, 2014, p. 22). The basic premise of religious literacy is that it is beyond academic achievement. The result of such a developmental approach should be that students would benefit from RE. That means that RE provides a means by which students can realise how, by studying this subject, they are enhancing their ability not only of religious understanding but also of themselves and their world (Erricker, 2010, p. 98).

Given the context of the research, it is more than clear that educational action research provides us with the opportunity for deeper research into the teacher's practice of building educational theory and also giving the teacher the space to be open to the possibility of making and creating worthwhile change, as well as for students to examine their own feelings and the thoughts that underlie their actions (Carr \& Kemmis, 2010; Elliott, 2010). Action research advocates the reflective paradigm of teachers' development which is challenged by the constructivist principle that teaching and learning must be structured in a personal and meaningful way and must also be constantly developed and adjusted (Elliott, 1983; Koutselini, 2010).

\section{The Research}

This particular action research takes into consideration the aforementioned role of the school, combining Religious Education's contribution to the social and emotional development of adolescents with the evaluation of the potential of a constructivist approach to the learning process which takes place in the harsh environment, comprised of poverty, diversity and uncertainty for the present and the future, in present day Greece.

The research has been organized by two experts in pedagogy in both the Departments of Theology and Primary Education at the National and Kapodistrian University of Athens (Lecturer in RE M. Koukounaras Liagkis and Emeritus Professor of Didactics E. Matsaggouras) and has been implemented by 10 undergraduate researchers of these departments. The research commenced in September 2012, and is now (2015) in its third 
year. The whole project was implemented with the cooperation of the school's RE teacher (Ms A. Alexandri), who graduated in Theology in 1987 and has 24 years experience in teaching mainly to early adolescents in Gymnasium (high school). The research is based on an educational intervention at the 1st Gymnasium in Aharne (a suburb of Athens) for pupils aged between 11 and 15. The sample population is all 128 students who enrolled in the 1st grade of Aharne Gymasium in 2012-13 and in 2015 are in the 3rd year of the school. The paper contains the findings of the two years (Table 1) and a comparison with a control group which is all the students (121) who enrolled in that school in the 1st grade in 2013-14. What is important in that school is that Aharne is a suburb with deep-rooted financial problems and significant diversity amongst the population. That is reflected equally in the sample population and the control group. The school does not keep religious data, but they are obliged to keep data for migration and how many ROM-children enroll every year in the school (Table 1).

As the ROMA (Romani) population in Greece has no permanent accommodation and school is not in their culture the majority of them usually drop out of school (Sample: 60 (2012-13), 14 (2013-14) Control Group: 36 (2013-14)) (Dousas, 1997). The Principal of the research school confirms that $100 \%$ of the students who dropped out in 2012-13 and 2013-14 were ROMA and the majority ( $>90 \%$ ) drop out school during September every year.

Table 1

Sample Population and Control Group

\begin{tabular}{|c|c|c|c|c|c|c|c|c|c|c|c|c|c|}
\hline & \multicolumn{6}{|c|}{ Sample population } & \multicolumn{7}{|c|}{ Control group } \\
\hline & Total & $\mathrm{m}$ & $\mathrm{f}$ & Immigrants & ROM & Drop-out & & Total & $\mathrm{m}$ & $\mathrm{f}$ & Immigrants & $\mathrm{ROM}$ & Drop-out \\
\hline $\begin{array}{l}2012-131 \text { st } \\
\text { grade }\end{array}$ & 128 & 70 & 58 & 9 & 62 & 60 & & & & & & & \\
\hline $\begin{array}{l}\text { 2013-14 2nd } \\
\text { grade }\end{array}$ & 72 & 37 & 35 & 10 & 21 & 14 & $\begin{array}{l}2013-141 \mathrm{st} \\
\text { grade }\end{array}$ & 121 & 64 & 57 & 13 & 46 & 36 \\
\hline
\end{tabular}

By taking into consideration the following, (a) the socio-cultural and economic conditions of the school environment, which are lower than the Greek national average; (b) the nature of the RE that is related to sensitive personal identity-data; and (c) the principles of the constructivist theory, which considers knowledge radically as the individual having the main role in constructing knowledge - the researchers attempt to answer the question whether the design of learning environments that are based on a series of activities within the constructivist learning framework is effective not only in the learning process, but also on inter-communication and "connectedness" between the members of the learning community. For that, they use researches and educational practices with interpretative-ethnographic methods. Basically the teacher researches herself while students do the same with the help of two "critical friends" (two experts) and at the same time a team of researchers use quantitative and qualitative methods to test findings and proceed to changes. The research is based on previous experience in RE research (Koukounaras Liagkis, 2009; Miller, O'Grady, \& McKenna, 2013) and its methods are:

- Diaries (experts' team, teacher, and students);

- Students' material that has been produced during the lessons individually or collectively (texts, paintings etc.);

- Written questionnaires were filled in anonymously at the start, at the end of and during the school year;

- Observation of lessons; 
-Written reports and evaluation of educational interventions that were planned focusing on particular research key questions (i.e. team working).

In the action research model, RE is seen as an ongoing interpretation in the relationships between the researchers, the community of educational practice and the inescapable frameworks (Figure. 1) (Afdal, 2010).

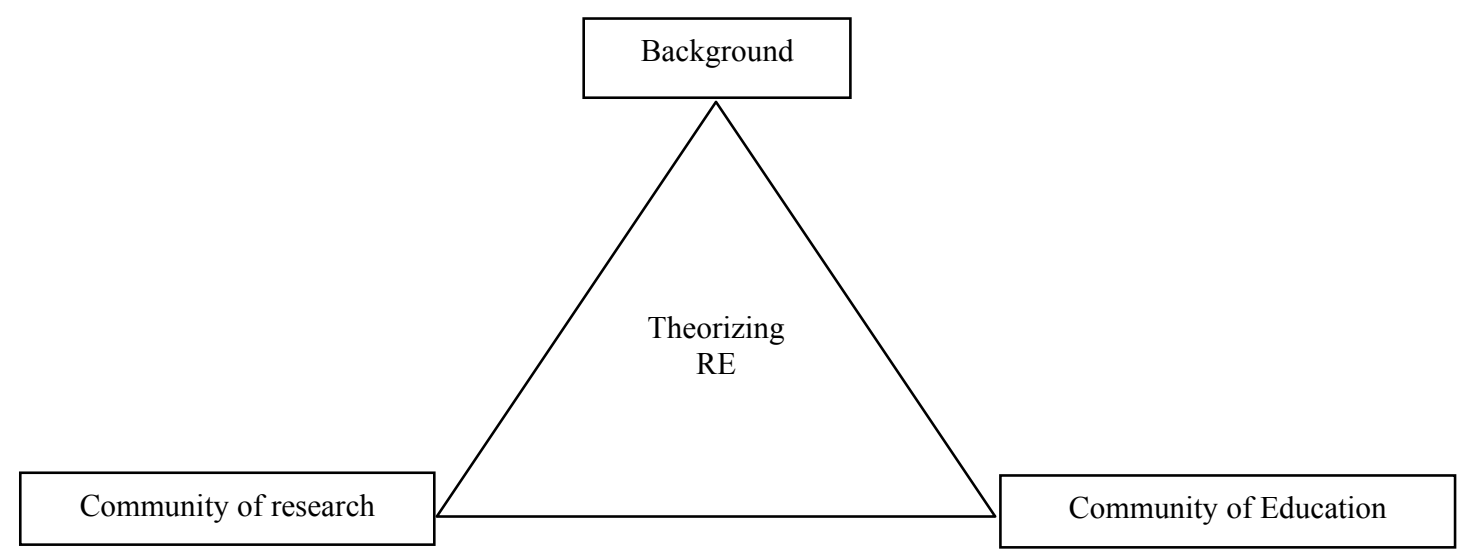

Figure 1.

\section{Key Findings}

In September, all the students answered a questionnaire about RE detailing their experiences from Primary school and after one year's research they came back again to answering questions evaluating RE, now in secondary school and amongst other its contribution to contact with others in class and their satisfaction gained from the pedagogical process. The results below point out a change in their opinion after a year and their appreciation of RE as a factor of connectedness (Table 2).

Table 2

Students Opinion About RE and Its Contribution to Community

\begin{tabular}{llll}
\hline $\begin{array}{l}\text { Enrolled in 2012-13 } \\
\text { (scale of 1 to 10) }\end{array}$ & $\begin{array}{l}\text { September } \\
(\mathrm{n}=76)\end{array}$ & $\begin{array}{l}\text { After one year } \\
(\mathrm{n}=60)\end{array}$ \\
\hline Positive opinion for RE & $9-10$ & $59 \%$ & $88 \%$ \\
Negative opinion for RE & $1-2$ & $16 \%$ & $5 \%$ \\
Environment of the classroom & $8-10$ & $48 \%$ & $55 \%$ \\
& $1-4$ & $18 \%$ & $8 \%$ \\
Acquaintance with others & $8-10$ & $12 \%$ & $70 \%$ \\
& $1-4$ & $26 \%$ & $5 \%$ \\
Interest of RE & $8-10$ & $16 \%$ & $63 \%$ \\
\hline
\end{tabular}

After the comparison with the control group which had been researched next year and were in the 1st grade too, there was no significant difference between the data of sample population and control group students, $t(9)=-.66, p=.53$.

Other findings explain to a degree the change in the sample population during the 1st grade to a more positive opinion for RE and why a large number of the students counted RE as a factor of intercommunication and connectedness. In the follow-up questionnaire, their first answer to the open question: "what do you 
remember from the procedure of the RE lesson during last year?" were (a) group collaboration $56.6 \%$, (b) activities $21.6 \%$, (c) pleasurable environment $8 \%$, (d) keeping a diary $8 \%$, (e) other $4 \%$, (f) nothing $2 \%$. The $\mathrm{RE}$ teacher noted in her diary that "during the year, they have really changed in how they behave towards each other, with whom they cooperate and to what extent they know one another. They had many opportunities to get to know each other, to collaborate and in many cases create new relationships". During the school year, almost every lesson was planned to be taught by facilitative and constructivist methods and 14 activities groups had to produce a project (text, painting, poster etc) which through their study and observation give us the ability to connect to a great extent cooperative learning with connectedness. Content and cluster analysis of the students' answers in their diaries which were kept in every lesson lend support to the claim that RE lessons create relationships between the students (more between boys than girls) and between the students and teacher. In the middle of the school year (February), all had cooperated in the classroom in two activities at least with each student of the class. In the same month the teacher noticed that "for first time in my career I know my students so well".

One of the questions in the diaries was "what did you like in the lesson today and what didn't you like?" The data gathered from the answers can be categorized in the first part of the question in four basic categories which are respectively (a) cooperation, (b) agreement with others, (c) conversation with others and (d) action and, in the second part of the question, only two categories which are (a) nothing and (b) hustle and bustle. The data appear to suggest that early adolescents appreciate what a constructivist lesson has as learning outcomes and moreover a lesson in the classroom could be a great opportunity to communicate with each other and develop social skills.

A number of students' statements from the diaries provide convincing evidence that RE classrooms can function to interconnect the members of the community regardless of their faith. "It is good to cooperate with others even if you don't like them because you know them better," wrote Sofia, "It is difficult for me to sit with $\mathrm{S}$ and $\mathrm{G}$ to discuss and present our project. But I learn something from them and that is important. RE helped me to accept S and G," wrote Sotiria, and "I understood that my faith would be stronger if I hear what others say to me even if I don't agree. Thus I will not be so egotistic," wrote George. Students agree that RE plays a role in preparing them to live and work in a diverse society. More than $50 \%$ of the students noted in their diaries that "they learn about religion and religions, they learn to be tolerant towards others and they have been challenged to take part in a dialogue" during the lesson. Moreover, in the observations of four lessons the two researchers stressed that although it is not easy for early adolescents to cooperate, especially in Greek education where there is no collaborative culture, (according to questionnaires, RE in Primary school was taught by the didactic and instructional method by more than 90\%), during the research year, the students cultivated their social skills and the main reason for that was the method of the lesson which offered opportunities for communication. The observers used the interaction process analysis of R.F. Bales to record the observation.

Further in March of the 2nd research year (2013-14), another questionnaire containing all the different subjects of the Curriculum illustrated students' perspectives about them and how they evaluated their teachers' lessons regarding (a) the interest of the lesson, (b) the explanations given of the difficult points, (c) the encouragement provided by the teacher, (d) the opportunities to participate and (e) the environment of the classroom (Table 3). 
Table 3

Students' Perspectives on the Subjects of the Curriculum (Sample Population 2013-14, $n=60$ )

\begin{tabular}{|c|c|c|c|c|c|c|}
\hline Subjects & & Interest & Explanations & Encouragement & Participation & Environment \\
\hline \multirow{4}{*}{$\begin{array}{l}\text { Religious } \\
\text { Education }\end{array}$} & 1 & $0 \%$ & $1.6 \%$ & $0 \%$ & $0 \%$ & $0 \%$ \\
\hline & 2 & $2 \%$ & $6.6 \%$ & $6.6 \%$ & $10 \%$ & $13.3 \%$ \\
\hline & 3 & $10 \%$ & $20 \%$ & $23.3 \%$ & $36.6 \%$ & $33.3 \%$ \\
\hline & 4 & $88 \%$ & $70 \%$ & $73.3 \%$ & $53.3 \%$ & $53.3 \%$ \\
\hline \multirow{4}{*}{ Arts } & 1 & $6.6 \%$ & $3.3 \%$ & $16.6 \%$ & $6.6 \%$ & $3.3 \%$ \\
\hline & 2 & $10 \%$ & $26.6 \%$ & $16.6 \%$ & $13.3 \%$ & $26.6 \%$ \\
\hline & 3 & $36.6 \%$ & $36.6 \%$ & $23.3 \%$ & $30 \%$ & $33.3 \%$ \\
\hline & 4 & $46.6 \%$ & $33.3 \%$ & $43.3 \%$ & $50 \%$ & $36.6 \%$ \\
\hline \multirow{4}{*}{ Maths } & 1 & $3.3 \%$ & $6.6 \%$ & $10 \%$ & $0 \%$ & $13.3 \%$ \\
\hline & 2 & $20 \%$ & $23.3 \%$ & $13.3 \%$ & $20 \%$ & $36.6 \%$ \\
\hline & 3 & $43.3 \%$ & $23.3 \%$ & $43.3 \%$ & $50 \%$ & $26.6 \%$ \\
\hline & 4 & $33.3 \%$ & $46.6 \%$ & $33.3 \%$ & $30 \%$ & $20 \%$ \\
\hline \multirow{4}{*}{ Physics } & 1 & $3.3 \%$ & $16.6 \%$ & $10 \%$ & $6.6 \%$ & $6.6 \%$ \\
\hline & 2 & $26.6 \%$ & $20 \%$ & $10 \%$ & $13.3 \%$ & $26.6 \%$ \\
\hline & 3 & $30 \%$ & $33.3 \%$ & $46.6 \%$ & $46.6 \%$ & $36.6 \%$ \\
\hline & 4 & $30 \%$ & $30 \%$ & $33.3 \%$ & $33.3 \%$ & $30 \%$ \\
\hline \multirow{4}{*}{$\begin{array}{l}\text { Physical } \\
\text { Education }\end{array}$} & 1 & $0 \%$ & $3.3 \%$ & $6.6 \%$ & $0 \%$ & $0 \%$ \\
\hline & 2 & $3.3 \%$ & $6.6 \%$ & $3.3 \%$ & $13.3 \%$ & $10 \%$ \\
\hline & 3 & $23.3 \%$ & $23.3 \%$ & $20 \%$ & $10 \%$ & $16,6 \%$ \\
\hline & 4 & $70 \%$ & $63.3 \%$ & $66.6 \%$ & $73.3 \%$ & $70 \%$ \\
\hline \multirow{4}{*}{$\begin{array}{l}\text { Greek } \\
\text { language }\end{array}$} & 1 & $6.6 \%$ & $6.6 \%$ & $3.3 \%$ & $3.3 \%$ & $3.3 \%$ \\
\hline & 2 & $13.3 \%$ & $13.3 \%$ & $16.6 \%$ & $16.6 \%$ & $20 \%$ \\
\hline & 3 & $50 \%$ & $46.6 \%$ & $40 \%$ & $33.3 \%$ & $40 \%$ \\
\hline & 4 & $30 \%$ & $33.3 \%$ & $40 \%$ & $46.6 \%$ & $36.6 \%$ \\
\hline \multirow{4}{*}{ History } & 1 & $13.3 \%$ & $13.3 \%$ & $6.6 \%$ & $3.3 \%$ & $10 \%$ \\
\hline & 2 & $33.3 \%$ & $20 \%$ & $23.3 \%$ & $30 \%$ & $26,6 \%$ \\
\hline & 3 & $23.3 \%$ & $26.6 \%$ & $30 \%$ & $26.6 \%$ & $26,6 \%$ \\
\hline & 4 & $30 \%$ & $40 \%$ & $40 \%$ & $40 \%$ & $36,6 \%$ \\
\hline \multirow{4}{*}{ English } & 1 & $6.6 \%$ & $6.6 \%$ & $10 \%$ & $6.6 \%$ & $3.3 \%$ \\
\hline & 2 & $23.3 \%$ & $20 \%$ & $16.6 \%$ & $16.6 \%$ & $36.6 \%$ \\
\hline & 3 & $30 \%$ & $43.3 \%$ & $16.6 \%$ & $36.6 \%$ & $26.6 \%$ \\
\hline & 4 & $40 \%$ & $30 \%$ & $56.6 \%$ & $40 \%$ & $33.3 \%$ \\
\hline
\end{tabular}

Notes: 1-not good, 2- neither good or bad, 3- good, 4- very good.

The comparison is not easy as the conditions differ for any subject. Same conditions (two hours per week, one teacher for all students), however, provides a compelling base to compare the data. In that case RE, Physical Education, English and Physics should be compared and there is overwhelming evidence corroborating the notion that students would benefit from RE as they found it the most interesting subject in the curriculum (Table 3) and supportive almost as much as Physical Education (see columns: encouragement, participation, environment in Table 3). It is worth mentioning that the subject has almost 0 "not good" answers. The data that are reported in Table 3 and the all the previous available evidence supports the claim that RE more than other subjects provides a means by which students can realise how by studying this subject they are enhancing their ability to communicate and understand (social and emotional development). After the comparison with the control group which had been researched the same year there was no significant difference 
between the data of the sample population and control group students, $t(5)=2.95, p=.03$.

Two more elements are worth mentioning as arguments that can be advanced to support the effectiveness of the pedagogical method in creating a community and in students' academic achievement. Firstly, during RE lessons, a number of students and the RE teacher raised awareness of poverty and hunger problems that other students confronted, so they organized in 2013-14 an initiative to ensure funding for a daily meal for their poorer classmates. Of course the principal and the other teachers embraced the initiative and the educational community (and parents) has retained that meal since the crisis has deepened in Greece. Secondly, the average of the marks in RE achieved by students in the final exam in 2012-13 and 2013-14 are higher compared (20-25\%) to the results of the three previous years when the RE teacher followed a more instructional method.

Of course a second-stage analysis would gain a deeper understanding of the RE classrooms during the school year and what kind of actions and interactions had influenced the learning community and its connectedness. It is fair to say, however, that there exist ethnic, social and family components that are negatively related to a sense of connection within the school. Although gender issues appear they are not seriously counted as factors influencing the results. Besides, a study of the RE teacher's teaching methods prior and after the educational intervention might have much to suggest about the pedagogical methods and their effectiveness, but an experiment may be inconclusive and not essential within an action research.

\section{Discussion}

The research lies at the heart of the discussion on the supportive dimensions of the school. It is literally unfair for children to live in such a stressful environment with no satisfaction, as many researches have put forward. This particular ongoing action research provides confirmatory evidence that school can support early adolescents' wellbeing when education and its aims anticipate that and give greater attention to issues of wellbeing. The findings, additionally, pose a compelling argument in favor of a constructivist approach to learning and teaching theory, since the students can achieve much in practice for their emotional and social development and their academic achievement. Moreover, RE as a curriculum subject could have a contribution to young people's social and emotional development when RE is totally based on knowledge procedures and has a more person-centred approach. That means that RE should be in service more of education than of religion. In fact now, that religions are straight on the agenda and Islam and other religions put forward major issues related to social cohesion and secularity, religion in education has great potential due pedagogical arguments.

Given that RE has caused much debate in scientific fields over the years, the aforementioned argument develops the claim that religion should not be excluded from the curriculum ostensibly due the positivist conviction that only scientific and empirical methods lead to knowledge. The research suggests that religious knowledge is of great value for early adolescents' development and life since it provides them with the knowledge and the language that facilitate communication and interpretation of the world. That means that in school we all need to learn more about our mother language and other languages too and, of course, we speak about religious languages.

Specifically this particular action research, which is participative and the researchers do research with the RE teacher, not simply on her, provides valid scientific theory that has great potential to initiate dialogue between researchers, scientists and policy makers about the place of RE in schools and a scientific reappraisal of it. The results of the study so far, as well as the second analysis and other future studies within an 
interdisciplinary context, could be used to open discussions concerning not only the inter-relation between education, culture, religion and society, but also the value of the individual's wellbeing for social cohesion.

\section{References}

Afdal, G. (2010). Researching religious education as social practice. Munster: Waxmann.

Arweck, E., \& Jackson, R. (Eds.). (2014). Religion, education and society: Young people, religious identity, socialisation and diversity. New York and London: Routledge.

Bausor, J., \& Poole, M. W. (2002). Science-and-religion in the agreed syllabuses: An investigation and some suggestions. British Journal of Religious Education, 25(1), 18-32.

Beraud, C. (2009). The role of religion in students' lives and their surroundings. In P. Valk, G. Bertram-Troost, M. Friederici, \& C. Beraud (Eds.), Teenagers' perspectives on the role of religion in their lives, schools and societies (pp. 397-408). Munster/New York/Munchen/Berlin: Waxmann.

Bertram-Troost, G. (2009). How do European pupils see religion in school? In P. Valk, G. Bertram-Troost, M. Friederici, \& C. Beraud (Eds.), Teenager's perspectives on the role of religion in their lives, schools and societies (pp. 409-422). Munster/New York/Munchen/Berlin: Waxmann.

Bronfenbrenner, U. (1989). Ecological systems theory. In R. Vasta (Ed.), Annals of child development (Vol. 6, pp. 187-250). Greenwich, CT: JAI.

Carr, W., \& Kemmis, S. (2010). Action research as critical educational science. In A. Campell \& S. Groundwater-Smith (Eds.), Action research in education. fundamentals of applied research (Vol. II, pp. 53-82). London: Sage.

Chater, M., \& Erricker, C. (2013). Does religious education have a future? Pedagogical and policy prospects. London and New York: Routledge.

Conroy, J. C., Wenell, K. J., \& Lundie, D. E. (2013). Does religious education work? A multi-dimensional investigation. London-New Delhi-New York-Sydney: Bloomsbury.

Dewey, J. (1958). Experience and nature. New York: Dover.

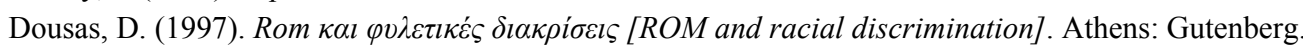

Eccles, J. S., \& Midgley, C. (1989). Stage-environment fit: Developmentally appropriate classrooms for young adolescents. In C. Ames, \& R. Ames (Eds.), Research on motivation in education (Vol. 3, pp. 139-186). New York: Academic Press.

Eccles, J., Early, D., Frasier, K., \& Belansky, E. (1997). The relation of connection, regulation and support for autonomy to adolescents' functioning. Journal of Adolescent Research, 12(2), 263-286.

Elliott, J. (1983). Legitimation crisis and the growth of educational action-research. Cambridge: Institute of Education.

Elliott, J. (2010). Building educational theory through action research. In A. Campell \& S. Groundwater- Smith (Eds.), Action research in education. fundamentals of applied research (pp. 171-194). London: Sage.

Erricker, C. (2010). Religious education. A conceptual and interdisciplinary approach for secondary level. London New York: Routledge.

Finn, J. D. (1993). School engagement and students at risk. Washington: National Center for Education Statistics.

Geertz, C. (1983). Local knowledge. New York: Basic Books.

Gray, J., Galton, M., McLaughlin, C., Symonds, C., \& Symonds, J. (2011). The supportive school. Wellbeing and the young adolescent. Newcastle: Cambridge Scholars Publising.

Grimmitt, M. (Eds.). (2000). Pedagogies of religious education. Great Wakering: McCrimmons.

Gustafsson, J.-E., Westling, A. M., Akerman, A. B., Eriksson, C., Eriksson, L., Fischbein, S., \& Persson, R. S. (2010). School, learning and mental health. A systematic review. Stockholm: Health Committee, The Royal Swedish Academy of Sciences.

Holley, L. C., \& Steiner, S. (2005). Safe space: Student perspectives on classroom environment. Journal of Social Work Education, 41(1), 49-64.

Jackson, R. (2014). Signposts—Policy and practice for teaching about religions and non-religious world views in intercultural education. Strasbourg: Council of Europe.

Jackson, R., Miedema, S., Weisse, W., \& Willaime, J.-P. (2007). Religion and education in Europe: Developments, contexts and debates. Munster: Waxmann.

Kalantzis, M., \& Cope, B. (2012). New learning. Elements of a science of education (2nd ed.). Cambridge: Cambridge University Press. 
Koukounaras Liagkis, M. (2012). Compulsory religious education: A justification based on European experience. In C. A. Shoniregun \& G. A. Akmayeva (Eds.), Ireland International Conferece on Education, 2012 Proceedings (pp. 44-48). Dublin: Infonomics Society.

Koukounaras Liagkis, M. (2013). Religious education in Greek public schools in Western Thrace: Identifying controversial issues. Mediterranean Journal of Social Sciences, 4(11), 274-281.

Koutselini, M. (2010). Participatory teacher development at schools: Processes and issues. In action research in education. Fundamentals of applied research (pp. 243-262). London: Sage.

Lähnemann, J. (2011). European map of interreligious and values of education. In J. Lähnemann \& P. Schreiner (Eds.), Interreligious and values education in Europe (pp. 85-98). Münster: PESC-Comenius Institut.

Marks, H. (2000). Student engagement in instructional activity: Patterns in the elementary, middle, and high school years. American Educational Research Journal, 37(1), 153-184.

McNeely, C., Nonnemaber, J. M., \& Blum, R. W. (2002). Prompting school connectedness: Evidence from the national longitudinal study of adolescent health. Journal of School Health, 72(4), 138-146.

Miller, J., O'Grady, K., \& McKenna, U. (2013). Religion in education. innovation in international research. New York and London: Routledge.

OSCE. (2007). The Toledo Guiding Principles on teaching about religions and beliefs in public schools, OSCE, Warsaw, 2007.

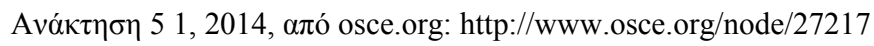

Regnerus, M. D. (2003). Religion and positive adolescent outcomes: A review of research and theory. Review of Religious Research, 44(4), 394-413.

Roebben, B. (2011). Seeking sense in the city. Berlin: Lit-Verlag.

Saroglou, V. (2014). Religion, personality, and social behavior. New York: Psychology Press.

Unesco. (2006). Unesco Guidelines on intercultural education. Paris: Unesco.

Valk, P. (2009). How do European students see the impact of religion in society? In P. Valk, G. Bertram-Troost, M. Friederici, \& C. Beraud (Eds.), Teenager's perspective on the role of religion in their lives, schools and societies (pp. 423-435). Munster/New York/Munchen/Berlin: Waxmann.

Vygotsky, L. S. (1978). Mind in society. The development of higher psychological processes. Harvard: Harvard University Press.

Walshe, K., \& Teece, G. (2013). Understandin "religious understandin" in religious education. Brithish Journal of Religious Education, 35(3), 313-325.

Watson, B. (2012). Why religious education matters. In L. Barnes (Ed.), Debates in religious education (pp. 13-21). London New York: Routledge.

Weisse, W. (2009). Quantitative study in the context of the REDCo Project-a foreword. In P. Valk, G. Bertram-Troost, M. Friederici, \& C. Béraud (Eds.), Teenagers' perspectives on the role of religion in their lives, schools and societies (pp. 9-12). Münster: Waxmann.

Wentzel, K. R. (2012). Teacher-student relationships and adolescent competence at school. In T. Wubbels, P. den Brok, J. van Tartwijk, \& J. Levy (Eds.), Interpersonal relationships in education. An overview of contemporary research (pp. 19-36). Rotterdam/Boston/Taipei: Sense.

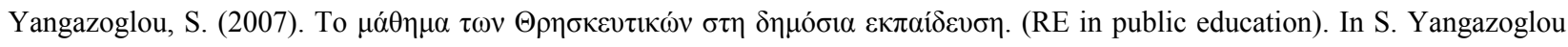

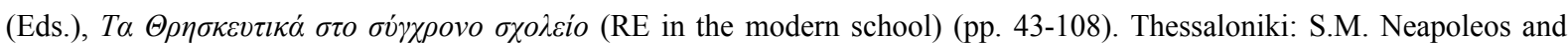
Stavroupoleos. 